\title{
The vagaries of IgM: a case report of EBV infection with concomitantly false-positive IgM for CMV, VZV, and HSV
}

\author{
Raai Mahmood ${ }^{1,2^{*}}$ (D) Khalid Mohamed ${ }^{1,3}$, Naba Saeed ${ }^{1}$, Kadhim Al-Banaa', Jonathan Zimmerman ${ }^{1}$ and Cecilia Big
}

\begin{abstract}
Background: Serum IgM (immunoglobulin M) testing is commonly used to diagnose acute viral infections. However, most clinicians are unaware of the vagaries of IgM testing, including antigenic cross-reactivity between multiple viruses and risk misdiagnosis.
\end{abstract}

Case presentation: We report a case of infectious mononucleosis with concomitantly positive IgM for EBV, CMV, VZV, and HSV.

A 26-year-old man presented with acute infectious mononucleosis picture. His blood work showed a total bilirubin level of $7.7 \mathrm{mg} / \mathrm{dl}$, ALT $1077 \mathrm{U} / \mathrm{L}$, AST $806 \mathrm{U} / \mathrm{L}$, ALP $325 \mathrm{U} / \mathrm{L}$, and INR 1.0. Monospot was positive; peripheral blood smear showed atypical lymphocytes; however, because EBV infectious mononucleosis does not typically cause elevation of liver enzymes over 1000, other etiologies were explored. Tests for hepatitis A, B, C, HIV, ANA, and ASMA returned negative. IgM for EBV-VCA, CMV, HSV, and VZV all returned positive, and the diagnosis of EBV IM was called into question. Subsequent tests of CMV and HSV PCR for viral load were negative (VZV was not clinically suspected), and later on, EBV-EBNA returned negative and EBV-VCA IgM and IgG returned positive, confirming the diagnosis of acute EBV infection.

Conclusion: We believe that lgM seropositivity can result from cross-reactivity among several viruses (especially herpes viruses), and although often relied on, a positive lgM should not serve as the sole determinant for diagnosis of acute viral infections.

Keywords: False-positive, False IgM, Cross-reactivity

\section{Background}

Serum IgM testing is commonly used to diagnose many acute viral infections. However, despite many reports of false-positive results, most clinicians are unaware of the vagaries of IgM and they risk misdiagnosis. Here, we report a case of infectious mononucleosis with concomitantly positive IgM for EBV, CMV, VZV, and HSV

\footnotetext{
* Correspondence: Raai.mahmood@beaumont.org

${ }^{1}$ Beaumont hospital of Dearborn, Dearborn, MI, USA

${ }^{2}$ Southgate, USA

Full list of author information is available at the end of the article
}

\section{Case presentation}

A previously healthy 26-year-old man presented with several days' history of fever, fatigue, nausea, and vomiting. He reported no illicit drug or alcohol use, no STD exposure, and no use of over-the-counter medications. He was noticed to have scleral icterus, palatal petechiae, and posterior cervical lymphadenopathy. Blood work revealed a lymphocyte predominant WBC of 16,000 cells/ uL, total bilirubin of $7.7 \mathrm{mg} / \mathrm{dl}$, ALT $1077 \mathrm{U} / \mathrm{L}$, AST 806 U/L, ALP $325 \mathrm{U} / \mathrm{L}$, and INR 1.0. UDS; acetaminophen and alcohol levels were all negative. His Monospot test was positive, and the peripheral smear showed atypical lymphocytes, but because EBV infectious mononucleosis (IM) does not typically cause elevation of the liver

\section{Springer Open}

(c) The Author(s). 2020 Open Access This article is licensed under a Creative Commons Attribution 4.0 International License, which permits use, sharing, adaptation, distribution and reproduction in any medium or format, as long as you give appropriate credit to the original author(s) and the source, provide a link to the Creative Commons licence, and indicate if changes were made. The images or other third party material in this article are included in the article's Creative Commons licence, unless indicated otherwise in a credit line to the material. If material is not included in the article's Creative Commons licence and your intended use is not permitted by statutory regulation or exceeds the permitted use, you will need to obtain permission directly from the copyright holder. To view a copy of this licence, visit http://creativecommons.org/licenses/by/4.0/. 
Table 1 Patient's LFTs, serological and virological tests during admission, one week and two weeks follow-up

\begin{tabular}{lll}
\hline Hospital & One week follow-up & Two weeks follow-up \\
\hline Monospot test +ve & & \\
EBV IgM +ve & & EBV-VCA IgM and IgG +ve, EBV-EBNA -ve \\
CMV IgM +ve & CMV PCR -ve & \\
HSV IgM +ve & HSV PCR -ve & \\
VZV IgM +ve & VZV PCR (not done) & \\
ALT 1077 & ALT 539 & ALT 96 \\
AST 806 & AST 309 & AST 59 \\
ALP 325 & ALP 371 & ALP 143 \\
Total bilirubin 7.7 & Total bilirubin 5.5 & Total bilirubin 1.7 \\
\hline
\end{tabular}

enzymes over 1000 , other etiologies were explored. Tests for hepatitis A, B, C, HIV, ANA, and ASMA came back negative; however, IgM for EBV-VCA, CMV, HSV, and VZV all returned positive and the diagnosis of EBV IM was called into question. Subsequently, tests for viral load were obtained; CMV and HSV PCR were both negative, and VZV was not suspected based on the clinical scenario, so it was not performed, and later on, EBV-EBNA returned negative and EBV-VCA IgM and IgG returned positive, confirming the diagnosis of acute EBV IM. See Table 1.

\section{Discussion}

Considering recent visit to his fiancée, compatible signs on physical exam (cervical LAD and palatal petechiae) and in addition to the presence of atypical lymphocytes in the blood smear and positive Monospot test suspicion for infectious mononucleosis was high; however, given the severity of the symptoms and significantly higher than expected elevation of the liver enzymes, we felt obligated to rule out other etiologies.

Viral hepatitis panel including Hep A, B, and C were negative. Acetaminophen level, urine drug screen, and HIV test were all negative as well. Autoimmune workup including ANA and ASMA was also negative.

To our surprise, IgM for CMV, VZV, and HSV in addition to EBV-VCA all came back positive.

Subsequently and in order to confirm/rule out those infections, we obtained viral load for CMV and HSV (both of which came back negative). VZV molecular testing was not performed given very low suspicion for the disease. EBNA antibody was negative; EBV-VCA IgM and IgG were both positive confirming acute EBV virus infection [1].

The first association of parvovirus with false-positive IgM for measles was described in 1994 in Alaska [2]. Also, false-positive IgM for EBV capsid antigen was reported in approximately in 3\% of patients with acute HIV and in $30 \%$ of acute hepatitis infection [3].
Different explanations have been suggested for this phenomenon such as concomitant infection with different viruses or reactivation of latent infection as EBV is known to cause transient immune suppression (this option was excluded in our case by negative viral load); it may also be the result of polyclonal stimulation of different B cells during acute EBV infection [4-6] or antigenic cross-reactivity especially among the herpes viruses [7].

Consequences for this phenomenon also vary; Landry ML et al. [8] describe several cases where a positive IgM titers and the clinical presentation did not "match." The diagnosis was then incorrectly based on the IgM titers leading to unnecessary testing and hospitalization, call back of high number of health care workers, inappropriate management of contacts, and even failure to provide antiviral therapy to meningitis cases.

\section{Conclusion}

We believe that IgM seropositivity can be a misleading diagnostic tool. False-positive IgM titers are common and have been reported in many cases; we believe that clinicians are still unaware and often over-rely on IgM titers to secure the diagnosis. IgM should not be used as the sole determinant of diagnosis and further confirmatory testing such as molecular tests or paired sera is required to confirm the diagnosis.

\section{Abbreviations}

IgM: Immunoglobulin M; EBV: Epstein-Barr virus; CMV: Cytomegalovirus; VZV: Varicella zoster virus; HSV: Herpes simplex virus; ALT: Alanine transaminase; AST: Aspartate transaminase; ALP: Alkaline phosphatase; INR: International normalized ratio; ANA: Antinuclear antibody; ASMA: Antismooth muscle antibody; EBV-EBNA: Epstein-Barr nuclear antigen; EBVVCA: Epstein-Barr capsid antigen

\section{Acknowledgements}

Not applicable

\section{Authors' contributions}

RM, MK, NS, KA, CB, and JZ were all involved in patient care; they also helped with literature review and were major contributors in writing the manuscript. All authors read and approved the final manuscript. 


\section{Funding}

Not applicable

Availability of data and materials

Not applicable

Ethics approval and consent to participate

Not applicable

\section{Consent for publication}

Not applicable

\section{Competing interests}

The authors declare that they have no competing interests.

\section{Author details}

${ }^{1}$ Beaumont hospital of Dearborn, Dearborn, MI, USA. ${ }^{2}$ Southgate, USA.

${ }^{3}$ Medical College of Wisconsin, Milwaukee, USA.

Received: 11 May 2020 Accepted: 18 June 2020

Published online: 29 September 2020

\section{References}

1. John E. Bennett \& Raphael Dolin \& Martin J. Blaser. Mandell, Douglas, and Bennett's Principles and Practice of Infectious Diseases. 9th ed. Philadelphia, PA: Elsevier, c2020. Chapter138, Epstein-Barr Virus (Infectious Mononucleosis, Epstein-Barr Virus-Associated Malignant Diseases, and Other Diseases), 138: 1872-1890.e7

2. State of Alaska Epidemiology (1994). False positive lab test result for measles -some disease actually parvovirus B19. State of Alaska Epdemiol Bull; No.26.

3. Post JJ, Chan MK, Whybin LR et al (2011) Positive Epstein-Barr virus and CMV IgM assays in primary HIV' infection. J Med Virol 83:1406-1409

4. Karner W, Bauer G (1994) Activation of Varicella -zoster virus specific IgA response during acute EBV viral infection. J Med Virol 44:258-262

5. Haukenes G, Virggen B, Boye B, Kalvens MB, FLO R, Kalland KH (1994) Viral antibodies in infectious mononucleosis. FEMS Immunol Med Microbiol 8: 219-224

6. Ward KN, Gary JJ, Joslin ME, Sheldon MJ (1993) Avidity of lgG antibodies to human herpes-6 distinguishes primary from recurrent infection in organ transplant recipients and excludes cross-reactivity with other herpes viruses. J Med Virol 39:44-49

7. Balachandran N, Oba DE, Hutt-Fletcher LM (1987) Antigenic cross-reactions among herpes simplex virus types 1 and 2, Epstein-Barr virus, and cytomegalovirus. J Virol 61:1125-1135

8. Landry ML (2016) Immunoglobulin M for acute infection: true or false. Clin Vaccine immunol. 23(7):540-545

\section{Publisher's Note}

Springer Nature remains neutral with regard to jurisdictional claims in published maps and institutional affiliations.

\section{Submit your manuscript to a SpringerOpen ${ }^{\circ}$ journal and benefit from:}

- Convenient online submission

- Rigorous peer review

- Open access: articles freely available online

- High visibility within the field

- Retaining the copyright to your article 